\title{
GEOLOGICAL HISTORY OF THE REDSTONE QUARTZITE ${ }^{1}$
}

\author{
BY FREDERICK W. SARDESON
}

(Presented by title before the Society December 30, 1907)

\section{CONTENTS}

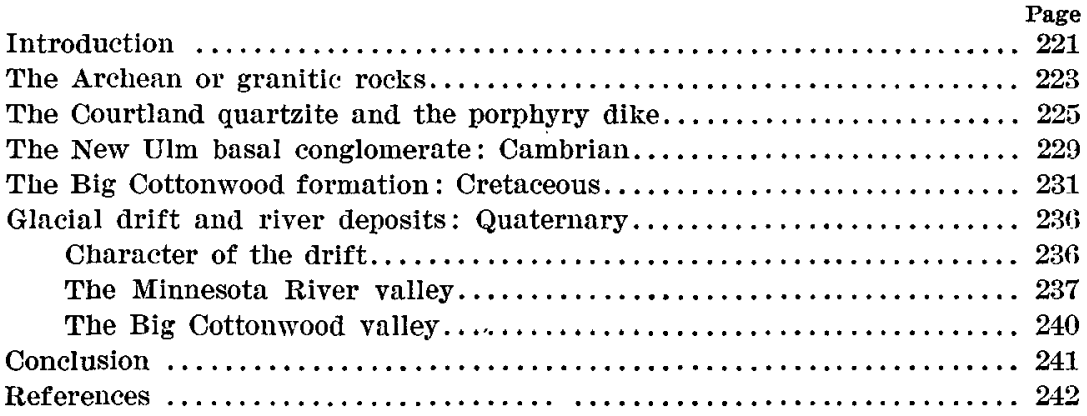

\section{INTRODUCTION}

Redstone, as it has been called for an indefinite number of years, is a conspicuous hill of quartzitic rock in the valley of the Minnesota river, midway between the towns of New Ulm and Courtland. The aim of this paper is to describe, geologically, this Redstone and the region which immediately surrounds it. The name Redstone, as used here, has never been employed as a geological formational name, and in the present paper it will be used for the particular hill, Redstone, while the term Courtland quartzite is the geologic formational name of the same rock. The old village of Redstone, which stands at the foot of the quartzite hill, has taken its name from that of the rock, rather than the name of the rock from that of the village.

The Redstone quartzite outcrops in an area of about 2 square miles east of the village of Redstone, on the left side of the Minnesota river, along the railway from New Ulm to Courtland, Minnesota. It is a conspicuous feature in the valley because the hill of rugged quartzite rises

\footnotetext{
1 Manuscript received by the Secretary of the Society March 23, 1908.
} 
about 175 feet high above the river's level and extends out from the northeast side of the valley so far as to turn the river from a direct course. The valley widens opposite this quartzite barrier-that is, on the other side of the river. None of this quartzite is seen on that side of the river and no such outcrops of it appear elsewhere along the valley, so that the Redstone has the appearance of an isolated block.

On the north side the quartzite extends under glacial deposits at the foot of a scarp which is the side of the valley. The highest point on the Redstone quartzite hill is in fact below the general surface level of the glacial drift on either side of the valley, and its position is such as to clearly indicate that it was once covered by glacial deposits, and that its uncovering from the drift has been due to the great glacial river Warren, which excavated the Minnesota valley to its present size. The quartzite being very resistant to erosion, the great river, which at first flowed over Redstone hill, later worked out an easier course around the south side of this rock mass. The Redstone quartzite has thus been left obtruding above the botiom of the valley. In similar manner, river silts of Cretaceous age, on the sides of the quartzite mass, show that in that age also it formed a prominence above a river. The Cambrian sedimentary rocks in turn appear as laid down about its foot, on the shores of an encroaching sea.

The Redstone, or Courtland quartzite, has therefore this distinction, that it stands in close relation, although unconformably with recent and Pleistocene deposits, with Cretaceous and with Cambrian, as well as with supposed Archean formations. These diverse formations are unconformable also, each to the other. The geologic history of the Redstone quartzite mass is to a large extent a key to the geologic history of the surrounding territory. Detailed account of these formations and their relations is given in following chapters.

In regard to literature concerning the Courtland quartzite and the formations about it, the work of C. W. Hall, Warren Upham, N. H. Winchell, and Leo Lesquereux are important. The first named author has summarized all the earlier literature on the quartzite and the granitic or gneissic rock in particular, and the other authors named embody the knowledge of the Cambrian, Cretaceous, and Pleistocene formations. A list of the works to which reference has been made is found at the end of this paper.

For opportunity to study closely the geologic formations around New Ulm, Minnesota, I am indebted to Dr 0. C. Strickler and the New UIm Commercial Association. For assistance and valuable geologic information, I am under obligation to Mr Benedict Juni, of New Ulm. 
The geologic field about the Redstone and the neighboring parts of the Minnesota and Big Cottonwood valleys has proved to be an inviting one. Each of the geologic formations demanded more complete investigation than had been accorded them before, partly by reason of advance in knowledge of correlative rock formations in neighboring regions which have been studied by geologists since the above-mentioned works were published and partly by reason of discoverable new evidence and needed correction of previous observations. Advance, which has been making in the knowledge of the "Iron ranges" and of the Baraboo, Wisconsin, region in particular; the changed interpretation of the Dakota sandstone formation, and the question of distinct glacial periods demanded review in relation to this region. Some rock exposures which had been called Cretaceous are found to be altered Archean granitic rock. A volcanic dike has been newly discovered in the Courtland quartzite at Redstone, and this affords good evidence on the question of structure and induration of that rock. Quartzite conglomerate is found to be Cambrian and not contemporaneous with the Courtland quartzite. The Cretaceous strata of wide extent are found to be fluviatile and lacustrine in origin rather than the product of the "Cretaceous ocean." The glacial deposits show two distinguishable till sheets with evidence of pre-glacial and inter-glacial valleys corresponding to the present Minnesota. As already indicated, the Redstone quartzite is of paramount interest in itself, besides having an important relation to the other formations. The accompanying geologic map (figure 1) shows the extent of the geologic formations.

\section{The Archean or granitic Rocks}

Two areas of granitic or gneissic rock appear in the region about Redstone. One of these is on the Big Cottonwood river and the other on the Minnesota. The former is the larger, but has not been before described excepting by Upham and Winchell. Upham refers $\left(6,{ }^{2}\right.$ volume 1, page 574) to it as a Cretaceous clay forming the base of a "section on the Cottonwood river south of New Ulm," which he cites from Winchell. It is described as follows:

"4. Fine somewhat gritty clay, largely aluminous. This is white and, when long submerged, soft and fiuid-like, but when dry has to be quarried by blasting. This, mixed at the rate of two-thirds with one-third of No. 3 , makes a fine, white firebrick-seen 12 feet."

This rock is in truth an altered or rotted granite in situ, rather than a Cretaceous clay. It has been bored into about 15 feet below the level of

${ }^{2}$ Figures in italic refer to citations at the end of this paper. 


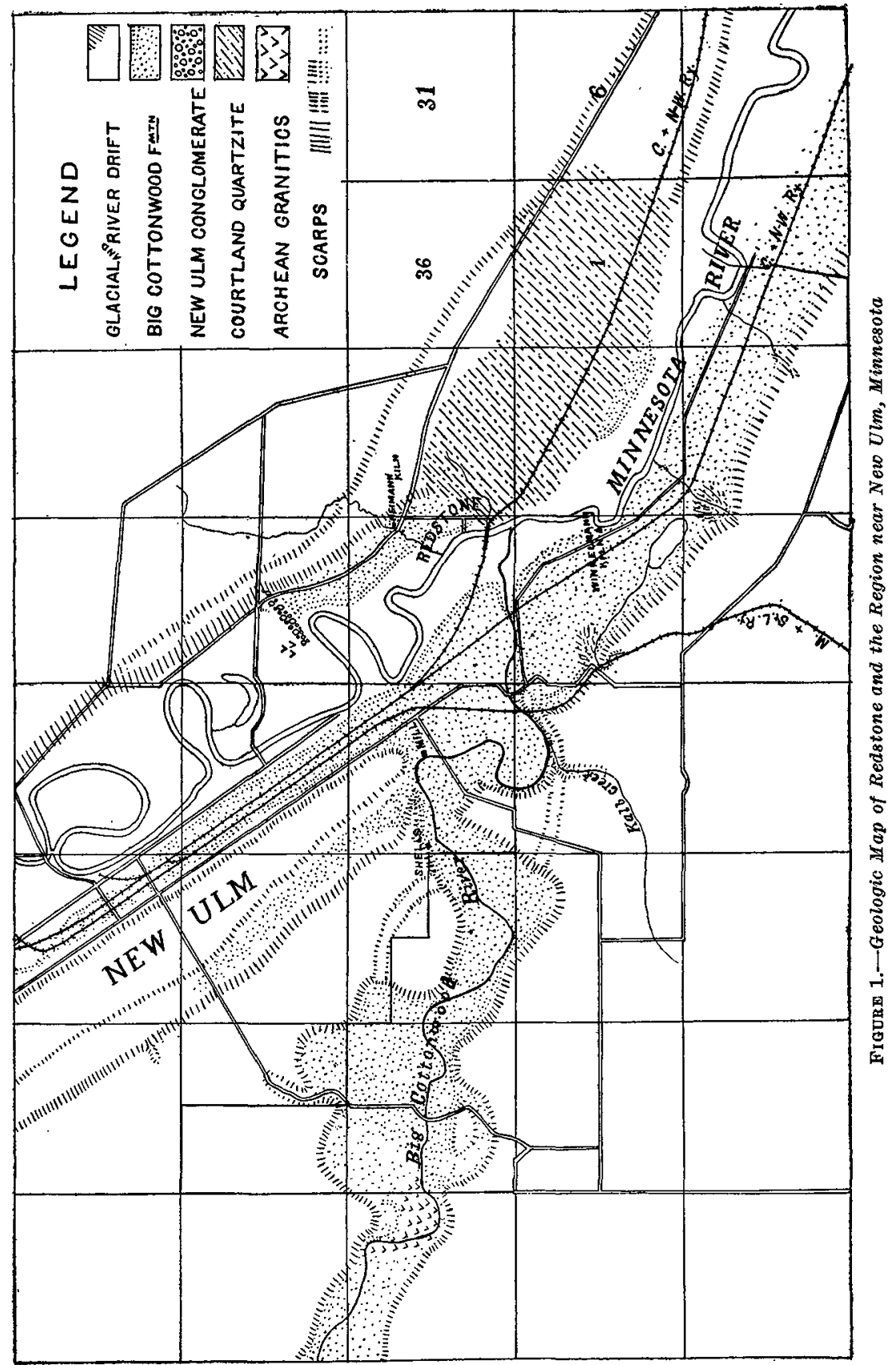


the river and is seen 10 or more feet above the river. It recurs in outcrops for half a mile down the river from the point, referred to by Winchell, where the brick were made. It consists of angular grains of quartz and small ferruginous concretions embedded in a kaolin groundmass, which is evidently altered-feldspar, etcetera. The rotting of the granite will be discussed in considering the Cretaceous. The depth to the unaltered granitic rock has not been determined, but I have mapped the area as that of a granitic rock (see figure 1), where only recent alluvial deposit covers it.

The area of granitic rock outcrop in the Minnesota valley lies at the margin of the floodplain of the river, on its left (east) side, opposite New Ulm. This is practically unweathered rock and, as well described by $\mathbf{C}$. W. Hall (10, page 25), it is "granitic in texture, of medium coarseness, somewhat porphyritic, and of reddish color, due to the abundance of red feldspar. It is hornblendic, but contains only a small portion of basic constituents, . . . ."Veins of white quartz 1 to 8 inches wide occur in it. The freshness of the rock here is due, I think, to the protection of a former covering of quartzite conglomerate which is seen outcropping still at 150 paces to the east of it. The surface of this exposure reaches to about 800 feet above tide, while that on the Big Cottonwood reaches nearer 850 feet. In the city wells of New Ulm, granite is said to have been struck at the depth of 190 feet-that is, at 650 feet above tide. At Shell's brewery, on the Big Cottonwood, it was not so deep. Evidently the granitic rock has an uneven surface and is yet of wide extent. Presumably it lies also under the Courtland quartzite, but at what probable depth will be considered in discussing that rock. Further, the erosion of the granitic rock and the alteration of its superficial part will be discussed in relation to the Cambrian and Cretaceous formations. The age of this rock is here assumed to be Archean.

\section{The Courtland Quartzite and the Porphyry Dike}

The ancient name Redstone could not be used for the quartzite formation of the Minnesota valley without confusion in terminology and it has not been adopted, although otherwise it would have been a very appropriate name. The term New Ulm quartzite is found in "North American Geologic Formational Names,"3 where its origin is accredited to Winchell $(5$, volume 2 , page $x x i i)$. It is, however, not evident that Winchell intended to introduce a new formational name. When he used the words "New Ulm and Pipestone quartzites (Potsdam)" he rather in-

2F. B. Weeks : Bulletin no. 191, U. S. Geological Survey, 1902. 
tended, I think, to say Potsdam at New Ulm and Pipestone. In the same volume in which this expression just quoted was used, Upham (6, volume 2, page 15\%) calls the formation "Potsdam conglomerate and quartzite," thus following Winchell, who says, in the preceding volume (volume 1, page 537), of the quartzite of Pipestone: "probably the equivalent of the New York Potsdam sandstone, but which Dr C. A. White, of the Iowa survey, has designated the Sioux quartzite . . . ." As formational names, the terms New Ulm and Pipestone would be at once synonymous with each other and with the name Sioux quartzite, and all these three with "Potsdam," according to Winchell, and it seems improbable that he intended to introduce the former as formational names. At a later date $(9$, page 157$)$ Winchell says:

"This seems to prove that the Sioux quartzite, the New Ulm quartzite, the Baraboo quartzite, and the Barron County quartzites are of the same age. . . ."

They are that which Wisconsin geologists have called Huronian, as Winchell also pointed out. Whether the words New Ulm quartzite were intended or not as a formational name, Winchell included under it two distinct areas of rock exposure, which now appear to be of very diverse age, namely, the quartzite at Redstone, in the township of Courtland, between the town of the same name and New Ulm, and the quartzite conglomerate seen near New Ulm.

Reference of the Redstone quartzite to the "Huronian" or to the "Potsdam" is not definite enough, and even the term Sioux quartzite, though undoubtedly applicable, is not such as to preclude the use of a term of narrower definition. I propose therefore to use the formational name Courtland quartzite here, with the understanding that the type locality is the Redstone near New Ulm. The name New Ulm will apply to the quartzite seen opposite that city.

Considering the Courtland quartzite, this formation at Redstone has been displaced and then profoundly eroded; so that the surface, which rises in a series of exposed scarps and soil-covered terraces from the river to the summit of the hill, is estimated to cross some 300 feet of strata in 150 feet elevation. The northern part of the area shows the lesser dip, and the southern side of the area shows the greater dip, so that in crossing it from north to south the general impression to me is that of approaching a great fault from the downthrow side.

C. W. Hall (10, page 22) finds, from an average of many observations in diverse places, that "the strike of the quartzites is north 60 degrees to 70 degrees west, and the dip varies from 5 degrees to 27 degrees north." 
Both cross-bedding and minor faulting interfere in the measuring of the dip. The most distinct evidence of faulting I discovered in a dike.

Dikes have not been heretofore reported here, though they were to be expected. The one which I have discovered is on the north side of the railway cut; in the quarry of the New Ulm Stone Company. It appears as a clay seam, a foot wide, perpendicular to the bedding of the quarry rock and crossing the quarry north 25 degrees east. It is exposed some 20 feet from the surface downward. The clay is dove-colored, with rhombic patches of white, marking it as a rotted or altered feldspar porphyry. The east or hanging wall is slickensided, and the dike is brecciated or crushed near it, so that white patches are drawn out into irregular seams, from which I infer that faulting had taken place parallel to the dike before the porphyry had altered to clay.

Since this undiscovered dike was at the railroad cut where all geologists have walked, evidently it was not easily recognizable until the quarry worked some distance into the hill. Many more such dikes may exist. The rock of the dike has been less resistant than the quartzite, so that rotting and erosion have made a depression at the surface where it outcrops and the depression is filled with soil and covered by regetation. Any other dikes would be likewise obscured. The quartzite also graduates from very hard to softer or "sandstone" areas, and these at the surface correspond with erosional depressions. To this the apparent terracing of the hillside is due (10, page 21 ). The many similar depressions may conceal also a few dikes.

Both the faulting and the erosion of the quartzite are difficult to rightly interpret without explanation of the phenomena of rock alteration. I take the view that the entire mass of rock now remaining at Redstone was once all vitrified, and the induration of sandstone to quartzite preceded the intrusion of lava now represented by the dike. Displacement then followed or in part preceded the intrusion. In the geologic ages since that time, the percolation of water down the joints has redissolved the cement, making "sandstone" patches and strata again. This view is not in accord with that expressed by Irving and Van Hise, who say (7, page 34$)$ :

"At Redstone the transition from argillaceous, reddish sandstone to completely vitrified, brick red to purple quartzite are frequent and abrupt. In places over considerable areas the appearance is as if the rock at higher levels had been vitrified by exposure. But in the railway cutting it is seen that the vitreous quartzites are not restricted to the exposed portions, but are interstratified with, and arranged in irregular areas in, an entirely unindurated crumbling sandstone. The peculiarly irregular distribution of the induration and the abrupt transitions from indurated to non-indurated material suggest the possibility of its production by descent along joints and spreading thence through the layers of a silica-bearing solution." 
In the quarry certain shallow erosional depressions on the surface of the rock overlie patches of sandstone within the flinty quartzite. The patches are kettle-shaped, two or more times as deep as wide. Other soft patches extend on either side of joints. The dike just mentioned, besides being itself altered to clay for 20 feet (as far as it is seen), is in contact with leached walls. The foot wall for 4 feet is light-colored, becoming then red. The hanging or east wall is soft, sandy, light-colored rock for 6 inches next to the fault line, and then 2 feet of light quartzite are followed by the normal read. In the neary-by railroad cut the jointing and the leaching of the rock are seen to follow the stratification largely. In texture the quartzite consists of crystalline sand grains which are enlarged, either interlocking or with interspaces filled by silica, which may be partly amorphous. The sandstone phase has also secondarily enlarged grains, lacking the cement. The sandstone may be the quartzite with the cement redissolved-that is, with the last deposited mineral first removed again by leaching. Again: "there seems to have been a cutting down of the original grains and the formation of a cryptocrystalline groundmass inclosing scattered and corroded grains of quartz" (10, page 22). Hall (place cited) attributes this corrosion of the sand grains to downward circulation of water, though he appears to hold as nearly as was practicable the same view as Irving and Van Hise regarding the induration of the rock, for he says: "The silica thus dissolved and removed has doultless acted as the indurating material for the underlying layers." The evidence of the deeply rotted volcanic dike in the quartzite argues that the leaching of the rock is vastly greater than has been realized heretofore. The induration also was originally general and deep, and the "sandstone" represents disintegrated rather than non-indurated rock.

By reason of the leaching and erosion as described, any original minor faults as well as dikes would tend to be concealed at the surface of the exposures. In the southern portion of the area, which is the more inclined and disturbed, the greater leaching and erosion has taken place, so that the lower strata appear there. Very evidently the hill of quartzite stands as it does because of the extreme resistance which the massive quartzite offers to erosion and weathering, and the relation of the Courtland quartzite to other rock formations should be interpreted accordingly. Some consideration may be given also to the fact that the lower strata are in part argillaceous, while the higher ones are rather uniformly pure and coarse-grained, becoming pebble-bearing or conglomeratic in certain of the strata.

The extension of the Courtland quartzite to the northeastward is indicated, as C. W. Hall says (10, page 23 ), by boulders strewn in the glacial 
drift 4 to 6 miles from Redstone. The formation at Redstone appears to continue in force, under the glacial drift, in that direction. To the west it seems to end abruptly, since the granite rises in place of it in the Big Cottonwood valley, as already described. The total thickness of the formation is not known. The estimated 300 feet of strata in the exposed portion may be too little or possibly too great an estimate. Concealed faulting may decrease the apparent thickness or possibly increase it. Likewise the extent of this formation between the lowest exposed stratum and the granitic rocks beneath it is uncertain, because the amount of downthrow which the quartzite has suffered in relation to the granities, seen westward of it, is unknown. The resistance of the quartzite to degradation from surface exposure is strikingly greater than that of granite, and therefore the relatively lower outcrops of the granitic rocks is not good evidence that they were not once as high or higher than the quartzite at liedstone. Since the extent of the original dislocation is unknown, the depth to granite under the quartzite is uncertain and, moreover, the existence of other geologic formations between them is possibly to be expected. Although it has been assumed by geologists that the quartzite at Redstone rested on the granitic rocks because these appear close below the New Ulm conglomerate quartzite, which was supposed to be the basal beds of the Courtland quartzite, yet there is reason for thinking to the contrary. That conglomerate is of Middle Cambrian rather than of the "pre-Cambrian."

\section{The New Ulm basat Conglomerate: Cambrian}

The quartzite conglomerate which outcrops on the left side of the Minnesota river, opposite New Ulm, a mile and a half above Redstone, has been heretofore considered by geologists as the basal part of the Courtland quartzite. It lies closely over the granitic rock; its strata dip 10 to 15 degrees, as if dislocated; it is a quartzite, and the contained pebbles, as reported, were all from formations older than the Courtland quartzite, whence the conclusion was easily drawn that it represents the basal part of the quartzite as seen at Redstone. In speaking of the contained pelbles in this conglomerate, Upham says (6, volume 2, page 159): "Neither the granite that outcrops close at the west nor the quartzite that occurs on a large area $1 \frac{1}{2}$ to 3 miles distant toward the southeast seems to be represented." C. W. Hall (10, page 23) makes essentially the same statement, and N. H. Winchell (9, page 156) says: "Probably there is no one who would call in question that this conglomerate and quartzite (that is, Courtland quartzite) are earlier than the Keweenawan eruptive age."

In company with Benedict Juni, I examined the ledges of the New Ulm 
conglomerate somewhat closely, and found pebbles of quartzite and even of quartzite conglomerate like the rock which is in situ at Redstone. By this criterion, the New Ulm conglomerate quartzite is later than the Courtland quartzite and may be of Cambrian age. Further, the fact that this conglomerate is indurated is not evidence that it is Huronian or that it is not Cambrian. Quartzite masses are not uncommon in neighboring sandstones; for example, in the Jordan sandstone on the Blue Earth river, and in the Shakopee formation at Mankato, and therefore an indurated conglomerate of Cambrian age is not anomalous. The dip of the beds in such a coarse, thickly packed, unassorted conglomerate may well be that of original cross-bedding, and the close relation or evident contact with the granitic rock is in accord with the known unconformability of the Middle Cambrian upon older rocks in Minnesota.

In regard to the contained pebbles, those of quartz and of jasper or taconite are very abundant, while those of fine-grained gneiss are few and those of quartzite are rare. The quartz may be considered as mainly derived from Minnesota Valley granites, and the quartzite from the Courtland quartzite, while the gneiss and jasper are from formations not seen, though probably existing in this region. Numerically considered, the quartz pebbles are most numerous and the granitic rocks are immediately near; the quartz pebbles are rarest, and the rock in situ is seen a mile away. Accordingly the schist and "taconite" and jasper may reasonably be derived from an intermediate distance. Many of the jasper and quartz pebbles of small size may be secondary from the Courtland quartzite. A single pebble of what appears to be an altered red granite and one of medium-grained, light-colored gneiss were collected. The absence of pebbles of the unweathered red gneissoid or granitic rock which is now exposed 150 paces west of the conglomerate may indicate simply that there was no outcrop of unaltered rock of that type there at that time in position to afford pebbles for this conglomerate. The conglomerate is not uniform in composition. For example, quartzite pebbles are to be sought in the middle of the exposure. It may be noted also that the pebbles are of diverse sizes and more or less waterworn and rounded. Some are etched or pitted and nearly all are quartzose and such as an encroaching sea might have gathered from a deeply disintegrated rock surface.

The New Ulm conglomerate may rest on either a weathered or a fresh surface, as far as we know. It is exposed 50 feet thick in all and 20 feet in single vertical outcrop. It is jointed with the bedding and forms strata 1 to 6 feet thick. The dip of these beds varies between 10 and 15 degrees, and the strike changes somewhat in direction, but it is "roughly represented by the direction of the exposure being north 15 degrees east" (Hall, 10, page 23 and plate III). The direction of the dip is at nearly 
right angles to that of the Courtland quartzite at Redstone, but conforms in direction with that of the Cambrian and Ordovician beyond the Redstone quartzite mass. The latter is in seaward direction from the New Ulm basal conglomerate, and its present elevation and position are such as to indicate that in the Cambrian sea it must have stood as a high island or peninsula, and that the New Ulm conglomerate is or was continuous with the Cambrian basal conglomerate east of Redstone as at Minneopa falls.

At Minneopa falls, near Mankato, on the south side of the Minnesota River valley, a well was bored 1,000 feet deep.

"In boring, 575 feet from the surface a conglomerate was reached with pebbles of clear, fine, non-granular quartzite up to 2 or more inches in diameter. From this deptl to more than 800 feet below the surface the borings consisted chiefly of quartzite pebbles indistinguishable in macroscopic and microscopic characters from the vitrified quartzite at Courtland. These pebbles are essentially different from those composing the 'basal conglomerate' beds opposite New Ulm" (Hall, 10, pages 23-24).

I have examined, with Professor Hall's permission, pebbles from the Minneopa well and find that they have surface pitting and general characteristic form of the quartzite pebbles from the New Ulm conglomerate. If both are, as they now appear to be, parts of the same Cambrian basal conglomerate, then the difference in the prevailing rock constituent of the pebbles is a local one, indicating that the rock types, as seen in the outcrop of the New Ulm conglomerate quartzite, are of local derivation.

The geologic formations which appear in the Minneopa well are traceable toward New Ulm. The Jordan sandstone disappears from over the Saint Lawrence shales before reaching Judson, at which place the latter outcrops for 1 or 2 miles. Beyond Judson a lower sandstone rises into view along the railway, but is not seen beyond Cambria. The Cretaceous shales appear between Cambria and New Ulm, showing that the Cambrian had been deeply eroded on the south of the Redstone after Cambrian time, since the Cretaceous lies doubtlessly in unconformity in its place.

\section{The Big Cotton wood Formation: Cretaceous}

Shales and sandstones of Cretaceous age have been heretofore recognized in isolated outcroppings on the Big Cottonwood river and in neighboring parts of the Minnesota valley. Fossil leaves from certain sandstone strata have been described by Lesquereux ( 4 and 8 ), and from evidence afforded by these fossil plants he referred the formation to the Dakota group. Certain green shales which were supposed to lie higher than the fossiliferous sandstone, have been referred to the Niobrara group by Winchell and Upham (6, volume 1, page 576 ; volume 2 , page 165$)$. 
In fact, the leaf-bearing sandstone is not under the green shales, but is quite the reverse. No such wide distinction as Dakota formation and Niobrara (that is, Colorado formation) is at all applicable, and not even a division into lower and upper formation is well defined. All strata are fresh-water deposits and are referable to the Dakota formation, although they possibly are contemporaneous with the marine Colorado formation or Niobrara. The name Big Cottonwood formation or beds will be useful in distinguishing this part of the Cretaceous in the region here described.

This formation extends continuously for 7 miles in the valley of the Big Cottonwood river, and is evident as far west as Springfield. From the Big Cottonwood valley it extends up the Minnesota to New Ulm and down the valley toward Cambria. It lies on three sides of the Redstone quartzite. The formation probably runs continuously westward toward Marshall, Minnesota, while it is cut off to the northeast and south, forming thus an area 20 miles or more long and 10 miles or less wide. It represents a river delta or filled valley of a stream which originally descended from east to west, as is shown in the cross-bedding in the strata. The Big Cottonwood formation now dips from west to east at about the same rate as the gradient of the Big Cottonwood river, the formation having been tilted.

The Big Cottonwood formation comprises coarse, clean sandstone and fine conglomerate, shales, potters' clay, limestone, and lignite. Alternate strata of almost any two kinds of materials may be seen locally. Owing to the prevailing and often very strong cross-bedding, no two exposures afford the same succession of strata. The color is red, green, white, yellow, blue, or brown. The deposit is clearly that of a river. Coarse, clean white or yellow sand occurs, in which there are seams of fine, tough, blue clay cross-bedding the sands at an angle of 10 degrees or less, and the sand frequently contains pieces of lignite, besides occasionally imprints of leaves.

There is no uniform division into upper and lower parts, but in general there are some differences between the lower and upper deposits. Limestone, which occurs at one end of the field, is in general median in position. It is found more particularly in the vicinity of the Redstone. The top of the formation is generally clean sand with clay seams or beds, which occur irregularly, but yet so that 40 feet of strata comprise 10 feet or less of clay, either in seams from a quarter of an inch to 1 foot thick or in several instances in a single thick bed. Below that there is red and green shale, sandy shale, clay, and some clean white sand, in strata which are 1 to 10 feet thick, but run unevenly. The lower part of the formation is 0 to 200 feet thick, as far as known, varying with the depth to subjacent rock, and comprises on the whole the greater part of the formation. 
Pieces of carbonized wood and leaves occur quite generally in the upper or sandy part of the formation, and in a few places very good fossil leaves were collected. Brown, soft sandstone and ferruginous concretions of very local and limited development contain the leaves. At the north side of the river, in the southeast corner of section 34, Milford, Brown county, is where the specimens described by Lesquereux $(8)$ were found. I have collected also in the northwest $1 / 4$ of northeast $1 / 4$, section 36 , Milford, and in the center of section 31, New Ulm. At the south end of the Minneapolis and Saint Louis railway bridge over the Big Cottonwood many good specimens were found. This is the very top of the formation, while the other localities are variously in lower position. The last-named locality is evidently where James Hall collected leaves which Lesquereux later identified. At this place a species of Pelecypod was also found by $\mathrm{Mr}$ Juni. Pieces of wood occur in lower strata and even in the limestone. In the limestone at Heimann's limekiln and at Winkelmann's there are undescribed Algal secretions, similar to the Schizothrix, which builds lime in the lakes of Minnesota in recent time. The fossil Algal skeletons appear as nodules made up internally of laminæ of granular lime, with open, clay-filled, or calcite-filled intervals between them.

A description of the Big Cottonwood formation from place to place would be very much detailed, owing to the many changes and exceptions to any rule which might be given, but a few places are instructive. In one place on the Big Cottonwood river (northwest $1 / 4$ of northeast $1 / 4$, section 36, Milford), where the rotted granite, as before described, rises 10 to 15 feet above the river, about 40 feet of 'sand belonging to the Big Cottonwood formation is seen between the granite and the glacial drift. In other places along the river the formation is thicker by reason of the surface of the granite being lower. There is generally 50 feet of strata above the river level. At New Ulm the top is at about 870 feet above tide-that is, 75 feet or less above the river at high water-and the formation is over 200 feet thick. At Redstone village the strata of limestone and shales are in contact with the Courtland quartzite. The same strata extend thence under the meadow land to the small creek which passes Heimann's limekiln and some distance toward, if not to, the New Ulm quartzite conglomerate. From the creek eastward along the wagon road up the hill, shales and clay are evident to the height of about 875 feet above tide. A complete section is not shown distinctly here, but from the bottom of the creek to the top of the section there appears to be $(a)$ limestone, 2 feet; $(b)$ clay, 20 feet; $(c)$ limestone, 2 feet; $(d)$ shale mixed with limestone, 15 feet; $(e)$ clay, 20 feet; $(f)$ limestone, 1 foot; (g) clay or shale, 20 feet. Sandstone is not seen. The limestone is "nodular" or "concretionary," consisting largely of lumpy Algal secre- 
tions from an inch to a foot in diameter and infiltrated with calcite. The lower limestones are largely "nodular," while those 20 and 40 feet higher up are more granular, laminated sedimentary deposit. The Algal limestone and the dominance of clay indicate that the area north of the Redstone quartzite, between it and the quartzite conglomerate ledge, was occupied by quiet water-a lake, in short. The lower limestones are represented, in their "nodular" form, on the west side of the Minnesota river south of Redstone, at Winkelmann's limekiln, and, again, as far as at the mouth of Kalb creek, there are thin sedimentary limestones and shales with flakes of lime in them, in a zone comprising 5 feet of strata. Traces of lime flakes occur 2 to 3 miles farther west.

Coarse sands with pebble-bearing strata are known only on the south of Redstone hill, and very evidently a river flowed by that course from east to west. This pebble-bearing sand occurs some 20 to 40 feet below the top of the formation, along the Big Cottonwood river, at the mouth of Kalb creek. The characteristically bright polished quartz pebbles appear also at New Ulm. This sand is known on the northeast side of the Minnesota River valley for several miles east of Redstone (in sections 16 and 20, Courtland, Nicollet county). The formation there appears to extend eastward, under the glacial drift. Two to 3 miles southeast and south of these last outcrops, Cambrian formations appear, rising to the same height and in place of the Cretaceous strata. The contact of Cretaceous and Cambrian I have not found, but doubtless the former lies here in an old valley, the south wall of which is of Cambrian rocks. Limestone is known on the south side of the Redstone close to the shelter of that rock, which formed locally the north wall of the Cretaceous valley. Shales should be expected to underlie the pebble-bearing sand, and they have in fact been traced on the right side of the Minnesota for 3 miles below the Big Cottonwood river. The coarse sand deposit is above sands and shales, indicating that stronger current followed as the Cretaceous valley filled.

In regard to the surface on which the Big Cottonwood formation rests, the evidence indicates a preexisting valley-practically a pre-Cretaceous valley. Since the strata rise to only half the height of the Redstone quartzite, or some 80 feet above the Minnesota river, the top of that rock may be supposed to have been exposed above the Cretaceous at all stages. The rotting of the dike, as described, and the leaching of the Courtland quartzite are evidently pre-Cretaceous in main. The granite outcrop on the Big Cottonwood river is rotted at least 30 feet and possibly 100 feet, and this would indicate that it had been a hill for ages before the Big Cottonwood formation of the Cretaceous began to surround it. The granite floor, as found in wells at New Ulm, is 300 feet below the top of 
Redstone and 200 feet lower than the granite outcrop on the Big Cottonwood, thus proving a considerable valley to lie buried here.

From the direction of the cross-bedding in the sands, as already described, the river is shown to have filled the valley just mentioned from east to west, and the original valley may also run east to west. I have searched for evidence of this valley and the Big Cottonwood formation along the Minnesota river below Mankato, Minnesota, and along the Bluc Earth and Le Seur rivers, which together make a north-to-south section crossing the line which the valley and formation must have followed if they extended that far. The clays and sandstones which are to be seen there, and which $\mathrm{N}$. H. Winchell and Warren Upham described as Cretaceous, are in fact only the rotted or residuary portions of Paleozoic sedimentary rocks in main. In places, 20 feet of clay occur with stratification partially preserved and with quartz geodes, silicified oolite, fossils, and other marks showing the original rock to have been the Oneota and Skakopee dolomites ; or, again, the same clay extends into depressions, or vertically into the dolomite as seams, or it fills "potholes," which same are leached and enlarged joints. Occasionally the leaching has made residuary clay in horizontal joints likewise. Original beds and strata of sand remain in the red clay. Such materials correspond to the rotted granite under the Big Cottonwood formation, and not to that formation. These residuary materials occur between 800 and 875 feet above tide, the main preserved part lying at 825 to 850 feet. On the Le Seur river (north line of section 2, town of Rapidan, Blue Earth county) there are 12 feet of clean gravel of finely polished siliceous pebbles, an inch or less in diameter, some of which are the remnants of Silurian and Devonian fossils. This rests on coarse sand 20 feet thick over the Jordan sandstone. The top of it is about 840 feet above tide. This gravel and sand correlates evidently with the Big Cottonwood formation, but it lies in a shallow valley, as the section along the river indicates. The cross-bedding in the gravel is from east to west. At one place a small pocket or lens of fireclay was formerly discovered over the gravel. It has now been mined out.

The evidence, of the leached rock floor and the Cretaceous sand and gravels along the Le Seur and Blue Earth rivers, and of the residuary clays in the Oneota dolomite near Mankato, Kasota, and Ottawa, along the Minnesota river, indicates that the general surface of the old land along that section lies now between 850 and 900 feet above tide and was originally high above the Big Cottonwood formation. From such a land area the red and blue shales, white sands, polished siliceous pebbles, and that which is now blue clay could have been derived. Between Kasota and Ottawa, and especially north of Ottawa, the rock wall is missing along the present Minnesota valley and possibly a pre-Cretaceous course, and 
the Big Cottonwood formation passes the river at that place in a general easterly direction from New Ulm. By reason of dip, the Cretaceous would lie below the river.

North of the Big Cottonwood the glacial drift is sufficiently intact to leave the question of former and present relation of the Cretaceous rocks greatly obscured. But, in the valley of the Minnesota river, the drift appears to extend down in place of the Cretaceous, from north of New Ulm, 10 miles to a place (some 6 miles north from the Big Cottonwood valley) where fresh granitic rock rises 25 feet above the river. Evidently both the Cretaceous rocks and the Archean granites have been greatly eroded there in post-Cretaceous, pre-Glacial time, and apparently a driftfilled valley crosses the course of the Minnesota river. At Sleepy Eye, which is north of the Big Cottonwood river, the granitic rock is said to be found in a well at a depth of about 200 feet-that is, at 800 feet above tide-no Cretaceous intervening between it and the drift. Absence of rotted granitic rock argues post-Cretaceous erosion.

\section{Glacial Drift and River Deposits: Quaternary}

\section{CHARACTER OF THE DRIFT}

The drift in the region about Redstone is mostly of boulder clay or till, although modified drift-gravel and sand-regularly accompanics the till. All the older rock formations of the region were doubtless once covered by glacial drift, as they are yet, excepting in the river valleys.

The surface of the drift outside of the river valleys is marked by irregular hills and closed basins, such as are characteristic of the glacial drift of the Wisconsin stage, but these irregularities occur with such monotony as to give the country the aspect of a nearly level land, sloping gently toward the Minnesota river. Two or 3 miles from the river the average altitude of the land surface is at or above 1,000 feet above tide, while along the border of the Minnesota valley few points only reach to 1,000 feet. One such point within the city limits of New Ulm is 1,015 feet.

The drift averages about 200 feet thick, but is far from uniform, because of the surface irregularities and the unevenness of the rock base upon which it rests. Redstone hill has the highest known rock subjacent to the drift. There the Courtland quartzite formation has been covered about 50 feet by till. The Big Cottonwood formation was covered from 100 to 150 feet deep. Northwest of New UIm the drift appears to extend to or below the river level, or 200 feet deep. The Big Cottonwood river cuts through the drift into the Cretaceous rocks for at least 7 miles above its mouth and probably all the way from Springfield, the till and associated gravel beds being 100 to 150 feet thick, as seen in the bluffs. 
There are two distinguishable drift sheets in this region, the same as have been generally recognized by Minnesota geologists (see Upham, 6, volume 1, page 580). These are the Wisconsin and probably the Kansan, as recognized in Iowa. They are best called Old and Young glacial drift, I think, for the present purpose. The Old glacial drift fills, as described, over an uneven surface, but presents apparently a rather uniform upper surface of its own, in general sloping from west to east. On the northeast side of the Minnesota river the top of this old drift is at about 890 feet above tide. The Redstone hill therefore stood above the surface of the Old drift, and it was probably on the west side of a wide shallow valley. On the Big Cottonwood river, 5 miles west of Redstone, the Old till rises to about 975 feet above tide. There is, as far as seen, a bed of fine, assorted and stratified, ferruginous, often cemented gravel, at the base of the Old drift. In one place, just above the mouth of Kalb creek, a small pre-Glacial channel, filled with a thin layer of till under strata of peat and clay with logs of wood, lies beneath the basal gravel bed. Such wood is found also in wells in the central high part of New Ulm city. A few lenses of fresh gravel occur also scattered in the till of the old drift. While the Old till is dark and compact, as a rule, it is locally leaching to reddish gray color at surface exposures and along water-bearing gravels.

On the Old drift rests the Young drift, with its rolling upper surface. It has a gravel bed at its base, as a rule, and other sand or gravel patches at the top. Of the two till sheets, the lower contains fresh Cretaceous sand and clay patches occasionally, besides lignite. The upper contains many pieces of a different lignite and has other differences-lighter color, looser texture, etcetera-but it consists so largely of materials of the old till as to be distinguishable mainly by its superposition. The Young drift is 10 to 100 feet thick.

Besides the Old and Young glacial drift, there are terrace deposits of gravel, sand, and clay in the river valleys. These deposits have come mainly out of the glacial drift and are, moreover, very closely associated with the same. They are found sometimes in confused relation with them. They were formed, moreover, during the time when the glaciers were yet retreating from the country, and technically they belong to the Glacial or Pleistocene period of the Quaternary age. In the Minnesota valley the terraces were made obviously by the great river Warren, which formed the outlet to the Glacial lake Agassiz, between the time of retreat of the ice from this region and its disappearance from the north.

\section{THE MINNESOTA RIVER VALLEY}

The Minnesota river for many miles above New Ulm has a direct, simple trough-shaped valley, with steep sides 200 feet high and with broad 
bottom a mile wide. This is the channel of the glacial Minnesota or "river Warren," where that river eroded into the glacial drift. At New Ulm the valley widens over the top and a system of terraces appears. The river Warren was also once divided here by an island which is now the site of the city of New Ulm (6, volume 1, page 582). At this place the valley is cut not only in the glacial drift, but also into the Big Cottonwood formation. At Redstone, 4 miles below New Ulm, the river Warren encountered the mass of Courtland quartzite, and this obstruction caused the river to widen its valley and build terraces even several miles above the obstruction. The terraces at New Ulm correlate largely with the stages of the valley's making at Redstone.

From the direction of the valley as it now lies at Redstone, it is readily seen that the river Warren flowed first directly across the present area of Courtland quartzite. At that early stage the river had only glacial drift to encounter, but after cutting its valley to a small depth the quartzite was met. This rock was highest on the left, and, being very resistant, it swerved the river gradually to its right side, and finally entirely beyond the west end of the quartzite formation. As the valley was gradually cut down, Redstone hill was thus uncovered and left extending half a mile out into the valley.

The making of terraces by the river might be attributed to three factors, namely, variation in flow of the stream, inequality in the quartzite barrier, and inequality of the other formations across which the river was diverted. Of these the first may be set aside, since elsewhere, especially above New Ulm, the valley indicates rather a constant stream. The relation of the stream and quartzite appears also to have been rather a uniform one. On the highest and earliest uncovered part of the quartzite its surface bears prior glacial striæ $(6$, volume 2 , page $165 ; 10$, page 21$)$, thus proving that the river scarcely cut the quartzite there; also, at lower levels, not much of the quartzite was removed. The surface there is in fact grooved, furrowed, and worn into irregular knobs and depressions, in the direction and manner of rapid stream erosion, by the river Warren; but yet the cause of this appearance of great erosion is that the leached and softened portions of the quartzite, as before described, was alone worn away. The firm quartzite appears thoroughly polished and generally rounded, but was in fact so little cut away that much, if not the greater part, of the softened or superficially leached rock was protected by it. While Redstone hill appears at first sight to have been worn into a rugged remnant by the river Warren, there is still better reason for thinking that the hill was practically an impregnable barrier to the stream. The course of the valley around the base of the hill is further evidence to this effect. The present form of the hill is therefore nearly 
its earlier one. Nothing appears, therefore, in erosion of the hill to produce terraces in the valley, and nothing also in the form of the hill to produce any other marked result than the swerving of the river Warren gradually to the right of it.

The making of the terraces may, however, be attributed to the third factor, namely, to that of unequally resistant geologic formations, which were cut into as the river evaded the Redstone quartzite. These evidently were the intact Cretaceous and Glacial deposits. Since the pre-Glacial drainage here ran, as before stated, north of the Courtland quartzite area and the inter-Glacial valley was on the east side of it, the post-Glacial valley which runs on the west side is therefore a new course, from New Ulm passing Redstone, and accordingly the geologic formations may be supposed to have been intact there when river Warren began its valley. Some portions of these formations are still found between Redstone hill and the river.

The formations which were eroded here by the river are the Young drift, the Old drift, and the Big Cottonwood formation, and each of these comprises hard and soft parts, such as to cause the erósion of a stream through them to progress by stages. The more resistant parts are (1) the boulder-clay of the Young drift, (2) that of the Old drift, (3) the tough clay beds at the top of the Big Cottonwood formation, and (4) the red shales at a lower horizon in the same. The river terraces correspond to the tops of these resistant parts, having formed by the erosion of the softer parts, namely, a loose gravel bed at the base of the Young drift, another at the base of the old drift, and the thick beds of loose coarse sand below the top of the Big Cottonwood formation. Whenever the river cut down to one of these at one point before others, the deepened channel could be readily widened by lateral erosion of the softer bed and undermining of the harder ones, from which presumably resulted terraces bounded by steep scarps, such as are now seen.

The surface of the terraces show generally a gradient greater than that of the present river, and they are covered with coarse gravel, and they appear to be remnants of rapids and rapidly sloping channels passing Redstone. Yet the terraces, although largely detached or interrupted, show generally a correspondence one to the other much as terraces of subsidence do. Their correspondence may be due rather to the control of the eroded geologic formations than to gradient of the river.

On the right side of the valley the highest, or 940-foot, terrace, resting on Young drift, forms the site where the cemeteries are located, on the west of New Ulm. The 910-foot terrace, resting on Old drift, forms the high central part of New Ulm city. The 870 -foot terrace is represented on the one side of the last by the abandoned channel back of the city 
proper, and on the other side by the level along which the business streets extend. A triangular tract 'on which the Minneapolis and Saint Louis railway runs south of the Cottonwood river is of the same. This terrace rests on the top of the Big Cottonwood formation. The 830-foot terrace is occupied by the depots and railway tracks at New Ulm and is traversed by the railways, extending to the Big Cottonwood river and thence three miles beyond it, occupying a great part of the valley opposite Redstone hill. It rests on the red shale zone of the Cretaceous. These terraces are covered generally by a few feet of red loam over more or less gravel, both of which were made by the river Warren.

On the left side of the valley the 940 -foot terrace runs nearly continuously from a mile above to four miles below the Redstone quartzite barrier ( 6 , volume 2 , page 173$)$. The 910 -foot terrace extends nearly a mile and the 830-foot terrace forms a broad meadow north of Redstone village. All these terraces in the valley passing the Redstone hill are in strong contrast to the simple valley above New Ulm.

\section{THE BIG COTTONWOOD VALLEY}

The valley of the Big Cottonwood river joins the Minnesota on the west side, opposite and a little above Redstone hill, just at the place where the river Warren was most diverted by that obstruction. Since the Big Cottonwood is tributary here, the cutting of its valley may be presumed to have proceeded pari passu with that of the Minnesota, and to have been influenced in somewhat the same way. The Big Cottonwood valley is a remarkably irregular one, as shown on the map (figure 1 ). It is nearly 200 feet deep, cut through the glacial drift and into the Cretaceous sands and shales; it has broad embayments, with terraces and steep sides. The river meanders from side to side in its valley and repeatedly undermines its bluffs, causing great landslides. Where the river encounters easily eroded sandrock the undermining is rapidly done, but where shales now appear at river level, the undermining is slow. The entire valley has been made in that same manner. The downward erosion has been accompanied by wide lateral erosion where soft rock was encountered by the river. The same succession of hard and soft formation is found along the Big Cottonwood as along the Minnesota valley at and below New Ulm, and since the two rivers cut down pari passu the terraces in the two valleys largely correlate.

While the Minnesota valley was made by a large, flood-like stream-the river Warren-and the modern stage of that river, the Minnesota, now meanders freely within it without conflict with the sides, the Big Cottonwood valley, on the contrary, has been made by a small river, as it now is, 
at all stages of its making. An old high channel, representing an early stage of the river, is found crossing section 32, New Ulm. This channel is sharply defined and in size indicates a river like the present one. It is cut through the upper glacial drift only. Another such channel, in section 4, Milford, runs across to the mouth of Kalb creek, and thence a little south of and parallel to the present river's course. The part of this channel below Kalb creek cuts across even the 830 -foot terrace, and therefore was followed by the creek as late as the modern stage of the Minnesota river; but that part above the creek was abandoned earlier.

The Big Cottonwood crosses the 830-foot terrace of the Minnesota valley, and it has there a narrow course, excepting above Kalb creek, where it meanders back against the bluff. At that place it made a wider way and evidently removed the larger part of what I call an 870-foot terrace, having intercepted Kalb creek. The narrow course or valley reveals the relation of the Big Cottonwood river to the Minnesota river in its modern stage. The earlier relation at the junction of the two valleys is not well shown by terraces, these having been cut away by the meanders of the Big Cottonwood. I am inclined to think, however, that there is a gravelfilled former channel of the Big Cottonwood river which runs through the 830-foot terrace from the mill in northeast direction to the Minnesota river and which was abandoned at a time when the 830-foot terrace still served as floodplain for the river Warren. The river has been a swift stream and heavily loaded with sediment at all stages, as it still is, and it could have cut and refilled a channel quickly.

Apparently the general effect of the tributary stream should be to crowd the river Warren and the Minnesota toward the opposite bluff-that is, against Redstone hill-by means of the loads of sand and gravel which must have been thrown into the side of the main valley.

\section{CONCLUSION}

From the foregoing descriptions it may be seen in particular that the Redstone quartzite, or that which now composes Redstone hill in the Minnesota valley, has stood with remarkably little change through many geologic ages. For the greater part of the time since the pre-Cambrian period its top has been exposed to destructive forces of the atmosphere. Its history may illustrate the many times greater power of resistance which a surface exposure of a quartzite mass may have over that of ordinary rock formations. Even the granite rocks and porphyry dike appear weak in comparison.

In pre-Cambrian time the quartzite was intruded and displaced, probably so as to lie lower than adjacent granitics, and then by the relatively 
rapid weathering away of these it came to again stand as a prominence above them. In Cambrian time it was met by the advancing ocean, which, instead of demolishing it, flowed around it, leaving a shore deposit of gravel even on its landward side. For several geologic ages the Redstone quartzite then stood as a great rock above a neighboring valley, much the same as the Baraboo quartzite of Wisconsin now stands. During Cretaceous time the river valley passing its south side filled with delta deposits, but probably leaving the top of the Redstone quartzite exposed well above the sedimentation plain. During the Tertiary, land erosion again made a valley, which was some 200 feet deep, crossing the granitic area to the north of the Redstone hill. During Pleistocene or Quaternary time the top of the quartzite was twice crossed by great glaciers. From the glaciers the rock received slight grooves and striations which are still clearly seen. They bear south 33 degrees east. The glaciers also spread sheets of till over it, although in inter-Glacial and in post-Glacial time erosion in part at least bared it again.

Although the geologic formations are all of scientific interest and have been described in detail in the preceding pages, the Redstone quartzite stands out as the most prominent feature in the geology of the area here described.

\section{REFERENCES}

1. Shumard, in Owen's Report of a geological survey of Wisconsin, Iowa, and Minnesota, 1852.

2. JAmes Hall: Notes upon the geology of some parts of Minnesota, etc. Transactions of the Philosophical Society, volume 13, new series, 1869.

3. N. H. WiNcheLL: Geological and Natural History Survey of Minnesota. Annual report for 1873 .

4. Leo Lesquereux: Cretaceous flora. U. S. Geological Survey of the Territories, volume vi, 1874.

5. N. H. Winchell: Geological and Natural History Survey of Minnesota, volume i, 1884 ; volume ìi, 1888.

6. WARREN UPhaM : Ioc. cit., volume i, chapter $\mathrm{xx}$; volume ii, chapter v.

7. R. D. Inving and C. R. VAN HISE: Secondary enlargements of mineral fragments in certain rocks. U. S. Geological survey, Bulletin 8, 1884.

8. Leo Lesquereux: Geological and Natural History Survey of Minnesota, volume iii, 1895, chapter i, Cretaceous fossil plants from Minnesota.

9. N. H. Winchell: A rational view of the Keweenawan. American Geologist, volume xvi, 1895 , pages 150 to 162 .

10. C. W. HALL: The gneisses, gabbro-schists, and associated rocks of southwestern Minnesota. U. S. Geological Survey, Bulletin 157, 1899.

11. N. H. WINCheLL: Geological and Natural History Survey of Minnesota, volume vi, 1901. 